\title{
Spillovers of US Conventional and Unconventional Monetary Policies to Russian Financial Markets
}

\author{
Shigeki Ono ${ }^{1}$ \\ ${ }^{1}$ Asahikawa University, Asahikawa, Hokkaido, Japan \\ Correspondence: Shigeki Ono, Faculty of Economics, Asahikawa University, 3-23, Nagayama, Asahikawa, \\ Hokkaido 079-8501, Japan. Tel: 81-166-48-3121. E-mail: s-ono@ live.asahikawa-u.ac.jp
}

Received: November 23, 2017

Accepted: December 5, 2017 Online Published: December 30, 2017

doi:10.5539/ijef.v10n2p14

URL: https://doi.org/10.5539/ijef.v10n2p14

\begin{abstract}
This paper investigates the spillovers of US conventional and unconventional monetary policies to Russian financial markets using VAR-X models. Impulse responses to an exogenous Federal Funds rate shock are assessed for all the endogenous variables. The empirical results show that both conventional and unconventional tightening monetary policy shocks decrease stock prices whereas an easing monetary policy shock does not increase stock prices. Moreover, the results suggest that an unconventional tightening monetary policy shock increases Russian interest rates and decreases oil prices, implying reduced liquidity in international financial markets.
\end{abstract}

Keywords: conventional-unconventional monetary policies, spillovers, VAR-X, Russia

\section{Introduction}

A series of unconventional monetary policies introduced by the Federal Reserve (Fed) in late 2008 provided liquidity through the asset purchase program. As the US economic conditions improved, the Fed started to taper off its asset purchases in 2014, followed by the Federal Funds rate hike to $0.25-0.5$ percent in 2015. These policy measures implemented by the Fed could influence financial markets, especially in emerging countries. According to Glick and Leduc (2012), there are several channels through which central bank asset purchases may affect long-term interest rates, including the portfolio balance effects of central bank asset purchases. Large-scale asset purchases can affect international asset prices and exchange rates as well because of global capital market linkages.

Several studies have investigated the international spillovers of US unconventional monetary policy to other countries (e.g., Ahmed \& Zlate, 2014; Ahmed et al., 2017; Anaya et al., 2017; Barroso et al., 2016; Bowman et al., 2015; Chen et al., 2016; Fratzscher et al., 2016; Gambacorta et al., 2014; Georgiadis, 2016; Hausman \& Wongswan, 2011; Rogers et al., 2014; Tillmann, 2016). This paper examines the spillovers of US conventional and unconventional monetary policies to Russian financial markets. The contributions of the study to the existing literature are as follows:

First, the impacts of US monetary policy on Russian financial markets are investigated (Note 1). This paper includes international oil prices in the models as Russia is one of the major oil producers and exporters, and thus Russian economic growth is largely affected by oil prices (Note 2). On the other hand, Bowman et al. (2015) and Chen et al. (2016) do not include Russia in their estimations. Fratzscher et al. (2017) and Hausman and Wongswan (2011) include Russia, but do not include oil prices.

Second, vector autoregressive models with exogenous variables (VAR-X models) are applied in the paper. The US monetary policy indicator, or the Federal Funds rate, is considered exogenous. This paper examines the responses of endogenous variables to a shock to the exogenous policy rate.

Third, the asymmetric effects of monetary easing and tightening regarding both conventional and unconventional monetary policies are investigated. Some studies reveal that the positive impact on stocks from an expansionary monetary policy shock is larger than the negative impact on stocks of a surprise monetary policy tightening (see, Rogers et al., 2014). This paper examines whether the above-mentioned tendencies can be applicable to Russian financial markets. Furthermore, the differences in the effects of conventional and unconventional policies are also investigated. 
Fourth, the shadow Federal Funds rate provided by Krippner (2016) is used in the estimations. The advantage of using this indicator is that it is applicable whether the Federal Funds rate is at zero or not.

The remainder of this paper is organized as follows. Section 2 describes data sources and methodological issues. Section 3 presents the empirical results of VAR-X models. Section 4 compares monetary policy effects. Section 5 estimates an alternative model. The last section concludes the paper.

\section{Data and Methodology}

This paper employs VAR-X models. Weekly data from the week ending on January 2, 2004 through the week ending on July 11, 2008, and from the week ending on December 19, 2008 through the week ending on September 30, 2016 are used in the analysis. Data from mid-July through mid-December in 2008 are not used because of dramatically large market value volatility caused by the global financial crisis.

Three endogenous variables and two exogenous variables were selected for the estimation of a benchmark model. The first endogenous variable is the weekly average values of the MICEX (st), which is Russia's major stock market index. The second endogenous variable is the weekly average Russian ruble exchange rate per one US dollar $(e)$. The third endogenous variable is the weekly average of the Moscow Interbank Offered Rate (MIBOR) $(r)$. The first exogenous variable is the weekly average values of the shadow US Federal Funds rate $(f f)$ provided by Krippner (2016), which has daily frequency (Note 3). The second exogenous variable is the international oil price $(o)$, which is the weekly average values of futures prices of New York Mercantile Exchange light sweet crude oil. All the series are expressed in logarithms and multiplied by 100 except interest rates, and the first differences of the variables are used in the model.

This paper sets up the following VAR-X model with a $p$ th-order lag polynomial:

$$
X_{t}=A_{0}+\sum A_{s} X_{t-s}+\sum b_{s} \Delta f f_{t-s}+\sum c_{s} \Delta o_{t-s}+\varepsilon_{t}
$$

Where $X_{t}=\left(\Delta s t_{t}, \Delta e_{t}, \Delta r_{t}\right), A_{s}(s=1, \ldots, p)$ is a three-by-three coefficient matrix, $b_{s}$ and $c_{s}$ are three-by-one coefficient vectors, and $\mathcal{E}_{t}=\left(\mathcal{E}_{s t}, \mathcal{E}_{e t}, \mathcal{E}_{r t}\right)$ ' is a three-by-one vector of serially uncorrelated disturbances.

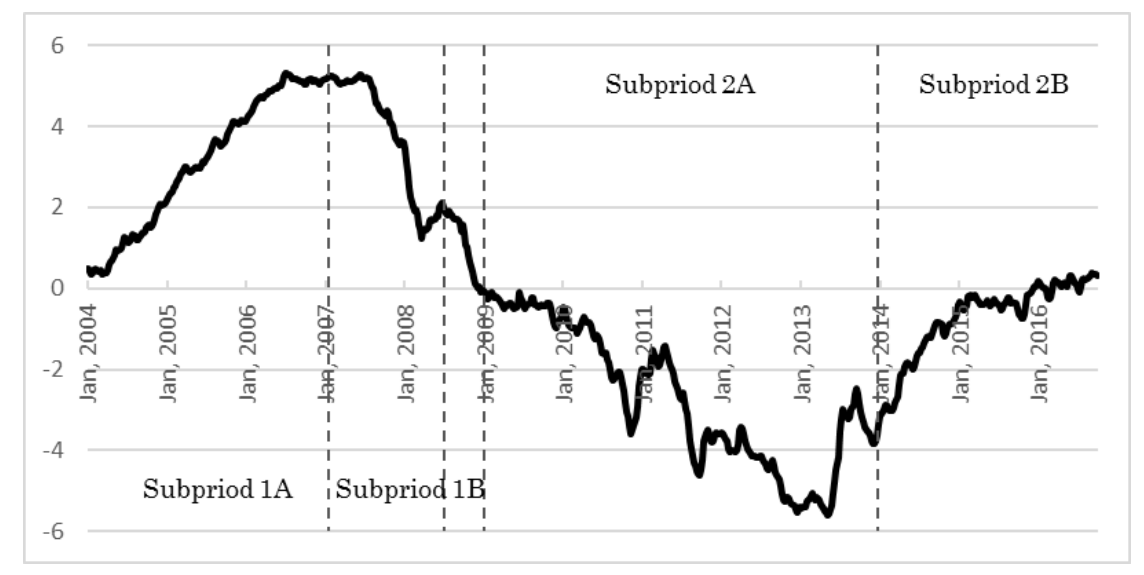

Figure 1. Krippner US federal funds rate

Source: Made by this author based on Krippner (2016).

\section{Empirical Results of VAR-X Models}

This paper divides Periods 1 and 2 into tightening and easing subperiods. Specifically, in Period 1 the tightening subperiod is from January 2, 2004 through January 12, 2007 (Subperiod 1A), and the easing subperiod is from January 19, 2007 through July 11, 2008 (Subperiod 1B). On the other hand, in Period 2 the easing period is from December 19, 2008 through December 20, 2013 (Subperiod 2A), and the tightening period is from December 27, 2013 through September 30, 2016 (Subperiod 2B) (see Figure 1) (Note 4). Figure 2 plots the dynamics of the international oil price, the MICEX, the ruble exchange rate against the US dollar and the MIBOR.

As for the lag length, four lags were applied in the models in order to ensure enough lags to examine monetary policy effects although the AIC suggests two lags. Next, impulse responses were assessed for all the endogenous variables up to 14 periods. Figure 3 shows estimated responses with confidence bands that reflect the 84th and 
16th percentiles of the distribution of 10,000 draws (Note 5). In the impulse response analysis of this paper a 1 percentage point Federal Funds rate shock is given in the monetary tightening phase while a minus 1 percentage point Federal Funds rate shock is given in the monetary easing phase.
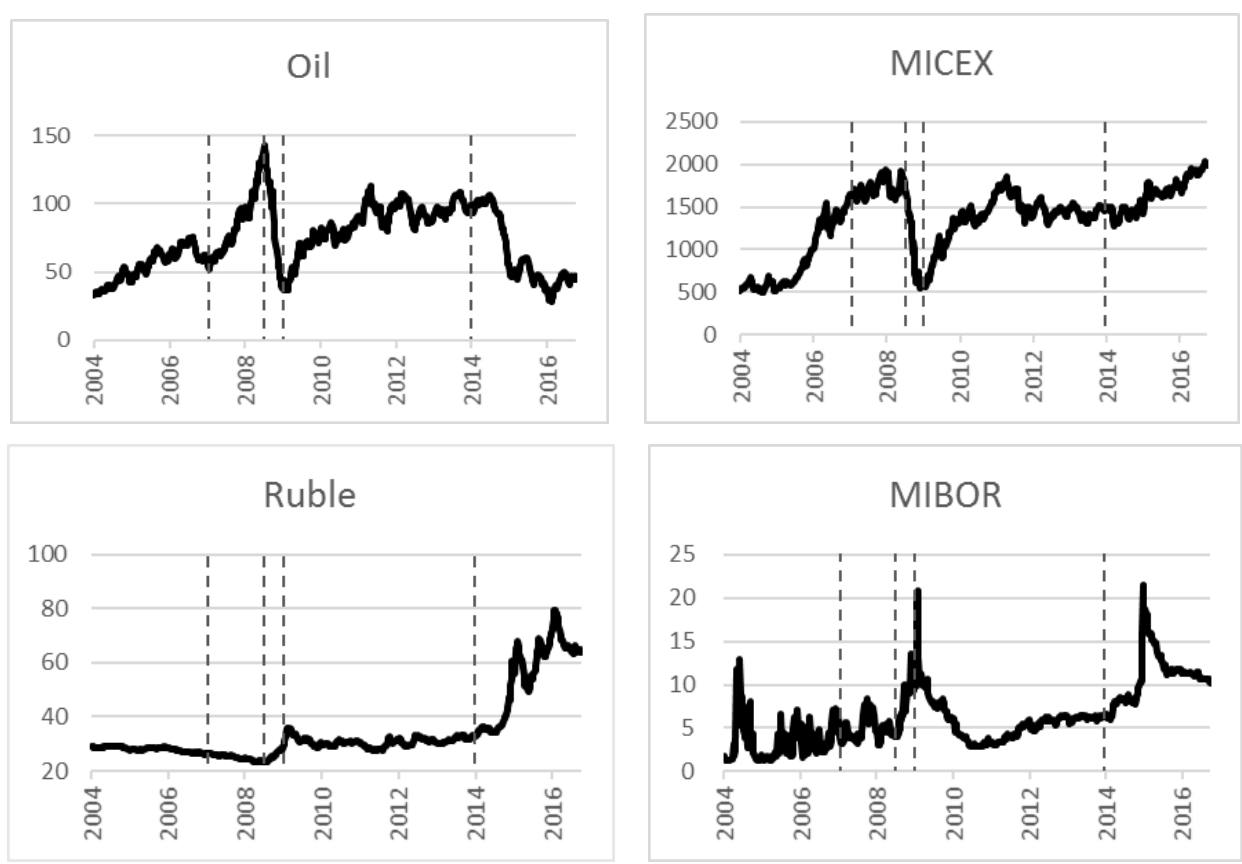

Figure 2. Dynamics of the oil price, the MICEX, the ruble exchange rate and the MIBOR

Subperiod 1A

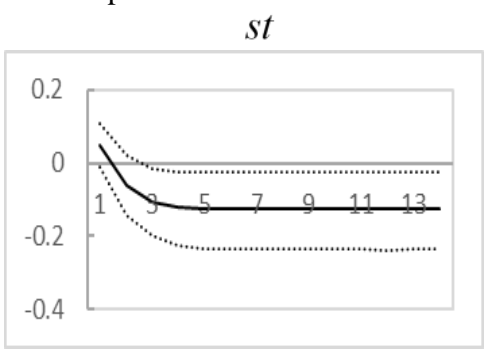

Subperiod 1B

st

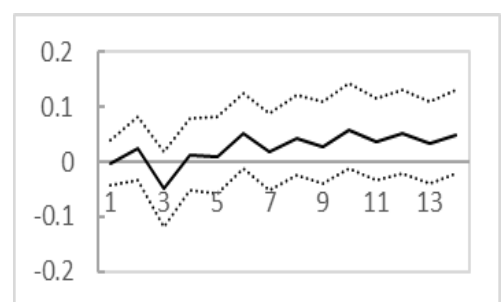

Subperiod 2A

st

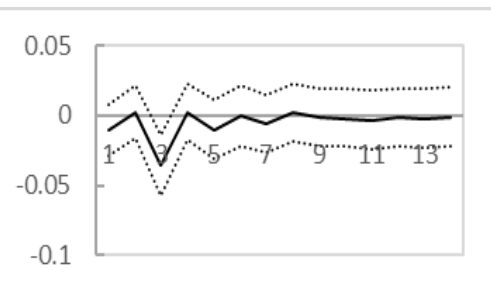

e

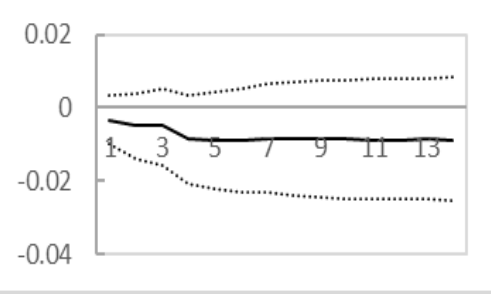

e

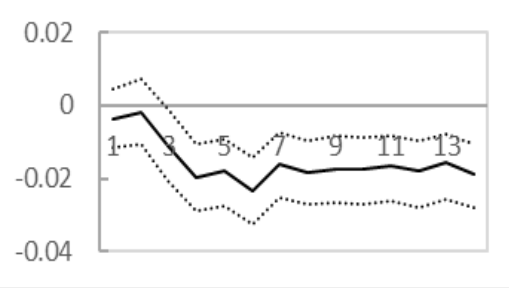

e

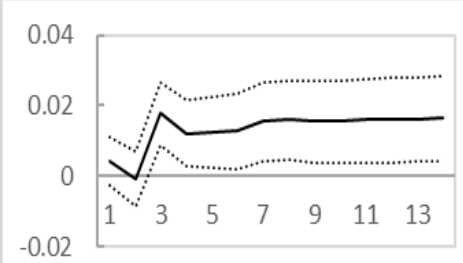

$r$

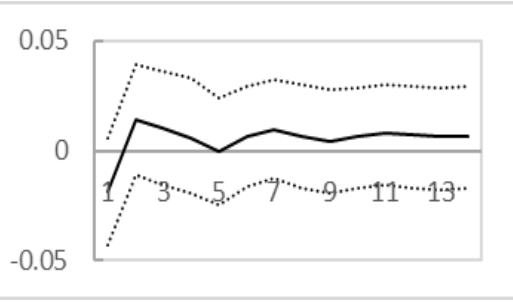

$r$

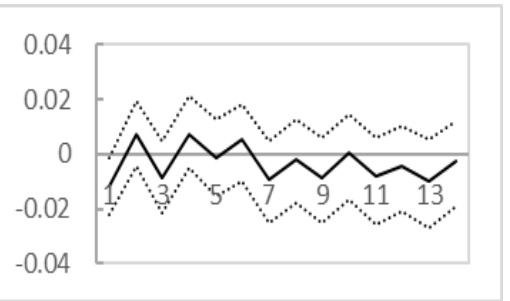

$r$

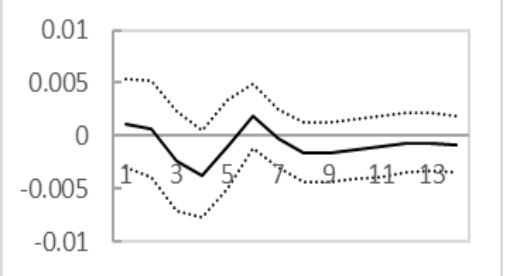


Subperiod 2B

st

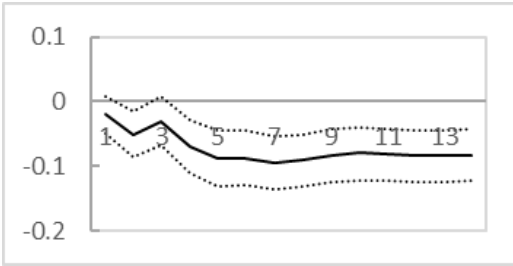

$e$

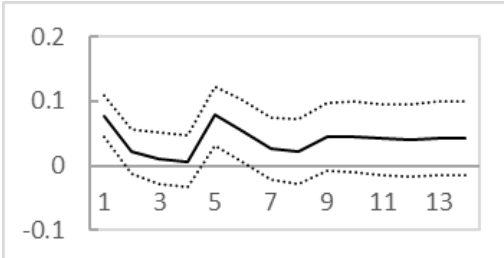

$r$

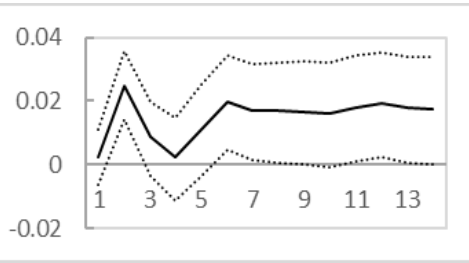

Figure 3. Impulse responses to a US Federal Funds rate shock

Subperiod 1A

$s t$

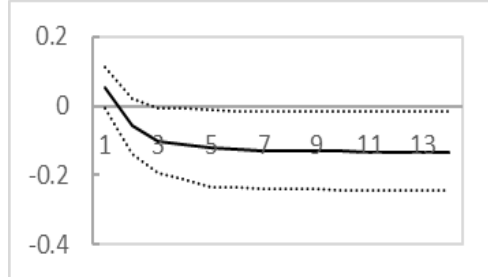

Subperiod 1B

st

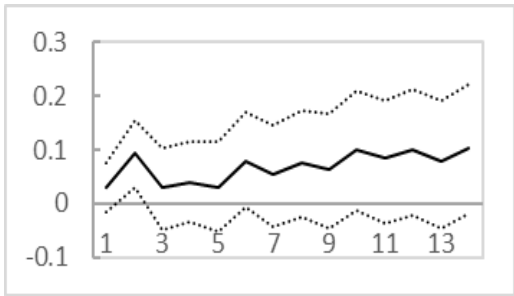

Subperiod 2A

st

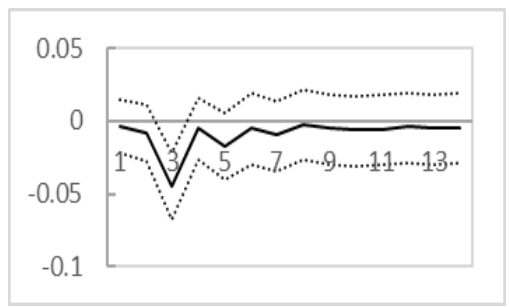

Subperiod 2B

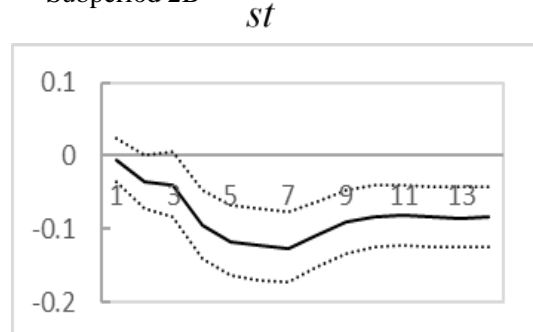

e

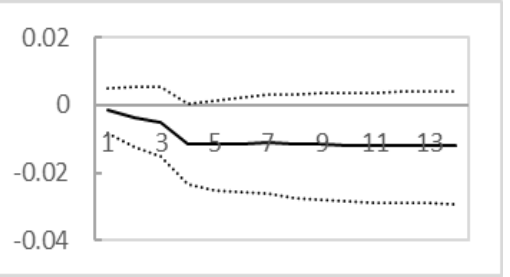

$e$

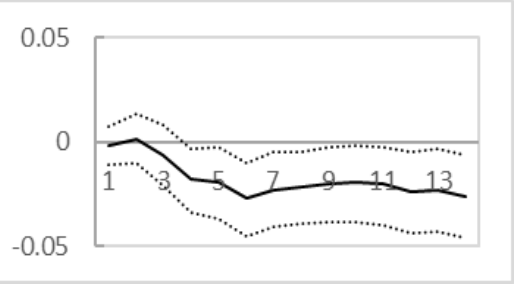

e

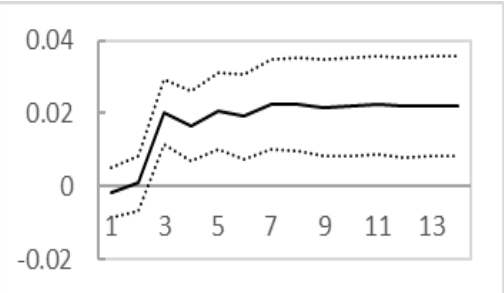

e

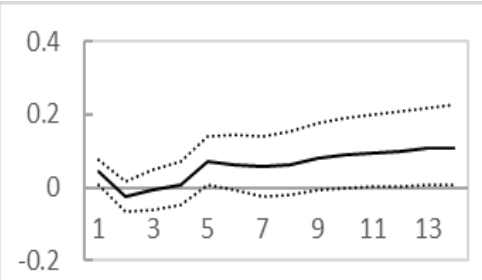

$r$

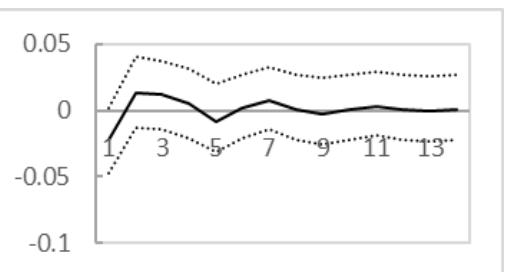

$r$

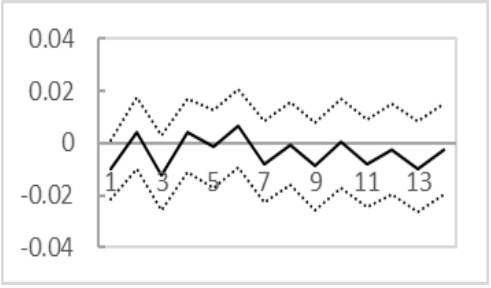

$r$

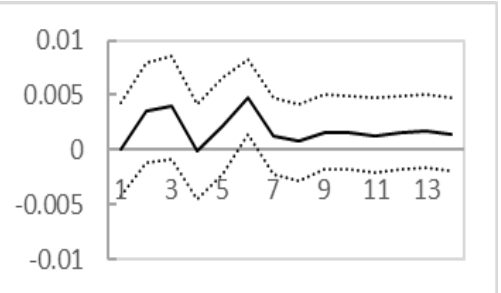

$r$

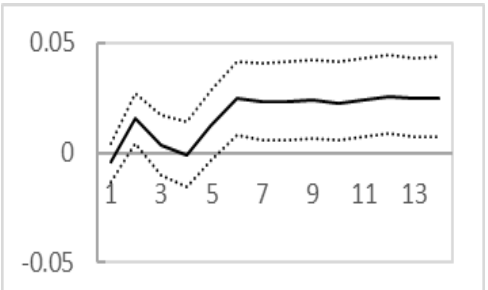

Figure 4. Impulse responses to a US federal funds rate shock for the alternative model

The main findings of impulse responses in the benchmark model are as follows. First, both conventional and unconventional tightening monetary policy shocks decrease the stock price index whereas an easing monetary policy shock does not increase the stock price index, suggesting that monetary policy acts like pulling on a string in an economic boom, contracting the economy, and acts like pushing on a string in a recession, producing little effect on the economy (Note 6). Second, an unconventional tightening monetary policy shock increases Russian interest rates whereas a conventional policy shock does not affect Russian interest rates. This implies that the exit 
from the US unconventional monetary policy decreases liquidity in international financial markets. Third, both unconventional easing and tightening monetary policy shocks depreciate the ruble (Note 7). The depreciatory responses of the ruble in Subperiod 2A can be explained by the increase in preference for the US dollar against the backdrop of Russia's sluggish economic conditions. The depreciatory responses of the ruble in Subperiod 2B reflect the oil price plunge as the shadow Federal Funds rate increases (Note 8). On the other hand, a conventional easing monetary policy shock appreciates the ruble, which reflects the decrease in US interest rates and the following depreciation of the US dollar, and oil price increases.

In alternative specifications, the US stock market index S\&P 500 is included in the model instead of oil prices in order to reflect US economic conditions and spillovers from the US to Russia. The responses of the stock price index, the ruble exchange rate and the MIBOR to a Federal Funds rate shock are almost the same as in the benchmark model (Figure 4).

\section{Conclusions}

This paper investigates the spillover effects of US conventional and unconventional monetary policies on Russian financial markets, using VAR-X models. The results of impulse responses show that regardless of conventional and unconventional monetary policies, a contractionary monetary policy shock decreases the stock prices whereas an easing monetary policy shock does not increase stock prices, suggesting that tightening monetary policy contracts the economy, and easing monetary policy produces less effects on the economy. On the other hand, an unconventional contractionary monetary policy shock raises Russian interest rates and decreases oil prices, implying the reduction of liquidity in international financial markets.

Future studies should address situations in other emerging countries and compare them with the situation in Russia.

\section{Acknowledgements}

This work was supported by JSPS KAKENHI Grant Number 17K03701.

\section{References}

Ahmed, S., \& Zlate, A. (2014). Capital flows to emerging market economies: A brave new world? Journal of International Money and Finance, 48, 221-248. https://doi.org/10.1016/j.jimonfin.2014.05.015

Ahmed, S., Coulibaly, B., \& Zlate, A. (2017). International financial spillovers to emerging market economies: How important are economic fundamentals?. Journal of International Money and Finance. 76, 133-152. https://doi.org/10.1016/j.jimonfin.2017.05.001

Anaya, P., Hachula, M., \& Offermanns, C. J. (2017). Spillovers of US unconventional monetary policy to emerging markets: The role of capital flows. Journal of International Money and Finance, 73, 275-295. https://doi.org/10.1016/j.jimonfin.2017.02.008

Barroso, J. B. R., da Silva, L. A. P., \& Sales, A. S. (2016). Quantitative Easing and Related Capital Flows into Brazil: measuring its effects and transmission channels through a rigorous counterfactual evaluation. Journal of International Money and Finance, 67, 102-122. https://doi.org/10.1016/j.jimonfin.2015.06.013

Bowman, D., Londono, J. M., \& Sapriza, H. (2015). US unconventional monetary policy and transmission to emerging market economies. Journal of International Money and Finance, 55, 27-59. https://doi.org/10.1016/j.jimonfin.2015.02.016

Chen, Q., Filardo, A., He, D., \& Zhu, F. (2016). Financial crisis, US unconventional monetary policy and international spillovers. Journal of International Money and Finance, 67, 62-81. https://doi.org/10.1016/j.jimonfin.2015.06.011

Fratzscher, M., Lo Duca, M., \& Straub, R. (2017). On the international spillovers of US quantitative easing. The Economic Journal. https://doi.org/10.1111/ecoj.12435

Gambacorta, L., Hofmann, B., \& Peersman, G. (2014). The effectiveness of unconventional monetary policy at the zero lower bound: A cross - country analysis. Journal of Money, Credit and Banking, 46(4), 615-642. https://doi.org/10.1111/jmcb.12119

Georgiadis, G. (2016). Determinants of global spillovers from US monetary policy. Journal of International Money and Finance, 67, 41-61. https://doi.org/10.1016/j.jimonfin.2015.06.010

Glick, R., \& Leduc, S. (2012). Central bank announcements of asset purchases and the impact on global financial and commodity markets. Journal of International Money and Finance, 31(8), 2078-2101. https://doi.org/10.1016/j.jimonfin.2012.05.009 
Hausman, J., \& Wongswan, J. (2011). Global asset prices and FOMC announcements. Journal of International Money and Finance, 30(3), 547-571. https://doi.org/10.1016/j.jimonfin.2011.01.008

Krippner, L. (2016). Documentation for measures of monetary policy. Retrieved from http://www.rbnz.govt.nz/-/media/ReserveBank/Files/Publications/Research/Additional\%20research/Leo\%2 0Krippner/5892888.pdf

Ono, S. (2011). Oil price shocks and stock markets in BRICs. The European Journal of Comparative Economics, 8(1), 29-45. http://eaces.liuc.it/18242979201101/182429792011080102.pdf

Ono, S. (2013). The effects of foreign exchange and monetary policies in Russia. Economic Systems, 37(4), 522-541. https://doi.org/10.1016/j.ecosys.2013.03.003

Ono, S. (2014). Causality relationship among oil price, stock index and exchange rate: Evidence from Russia. $\begin{array}{llll}\text { Acta Slavica } & \text { Iaponica, } & \text { 87-107. }\end{array}$ https://eprints.lib.hokudai.ac.jp/dspace/bitstream/2115/60017/1/ASI35_004.pdf

Ono, S. (2015). Bank lending channel in monetary policy transmission: Evidence from Russia. International Journal of Economics and Finance, 7(4), 1-11. http://dx.doi.org/10.5539/ijef.v7n4p1

Rogers, J. H., Scotti, C., \& Wright, J. H. (2014). Evaluating asset-market effects of unconventional monetary $\begin{array}{lllll}\text { policy: A multi-country review. Economic Policy, 29(80), 749-799. } & \end{array}$ https://doi.org/10.1111/1468-0327.12042

Tillmann, P. (2016). Unconventional monetary policy and the spillovers to emerging markets. Journal of International Money and Finance, 66, 136-156. https://doi.org/10.1016/j.jimonfin.2015.12.010

Wu, J. C., \& Xia, F. D. (2016). Measuring the macroeconomic impact of monetary policy at the zero lower bound. Journal of Money, Credit and Banking, 48(2-3), 253-291. https://doi.org/10.1111/jmcb.12300

\section{Notes}

Note 1. As for the effects of Russian monetary policy on the Russian economy, see Ono (2013) and Ono (2015).

Note 2. As for the impacts of oil prices on the Russian exchange rate and stock prices, see Ono (2011) and Ono (2014).

Note 3. This paper does not use the shadow Federal Funds rate calculated by Wu and Xia (2016) because its frequency is monthly.

Note 4. The FOMC statement announced the first reduction of QE3 on December 18, 2013.

Note 5. In draws, Jeffreys prior is applied to the covariance matrix and the posterior for the covariance matrix with that prior is inverse Wishart.

Note 6. The results are almost consistent with Bowman et al. (2015), who claim that a shock that lowers U.S. yields has a statistically insignificant effect on stock prices for all emerging countries in their sample.

Note 7. In the case of Bowman et al. (2015), the responses of the exchange rate to a monetary policy shock that lowers U.S. yields are not statistically significant except Brazil, which showed positive responses.

Note 8 . The negative responses of the international oil price to an unconventional contractionary Federal Funds rate shock were confirmed in other specifications, in which oil prices are treated as an endogenous variable (figures of the results are not presented to economize on space).

\section{Copyrights}

Copyright for this article is retained by the author(s), with first publication rights granted to the journal.

This is an open-access article distributed under the terms and conditions of the Creative Commons Attribution license (http://creativecommons.org/licenses/by/4.0/). 